DOI https://doi.org/10.18551/rjoas.2021-02.10

\title{
PURCHASING EXPERIENCE AND REFERENCE GROUP FOR PURCHASING DIGITAL MARKETING PRODUCTS
}

\author{
Pariasa Imaniar IImi*, Pertiwi Vi'in Ayu, Hardana Andrean Eka \\ Faculty of Agriculture, University of Brawijaya, Malang, Indonesia \\ *E-mail: Pariasa@ub.ac.id
}

\begin{abstract}
Consumers are the company's biggest asset. If a business wants to continue to grow and develop, the business actor must be able to understand and understand the desires of the various consumers. The purpose of this study is to describe the purchasing experience and reference groups that are used as a reference for consumers in purchasing products through digital marketing. Respondents of this study were consumers of UMKM products in the Greater Malang area who were taken as a representative sample with the conditions in the field. The probability sampling method is used to take samples with a total of 100 respondents. Reference group is used as a reference for consumers in purchasing products through digital marketing. The results of data processing use descriptive analysis. In general, the reference groups that influence digital product purchases are friends / spouses and family. The marketing approach and increasing consumer confidence must be built based on this closeness system through the purchase experience.
\end{abstract}

\section{KEY WORDS}

Consumer, referency group, digital marketing.

The development of information and communication technology causes significant social, economic, and cultural changes to take place rapidly, making the world without borders. One of the developments and advances in information technology is internet technology. The internet is said to be a new medium that has driven many changes in the world since the 1990s.

The advent of the internet has changed the way people communicate, do business, and also campaign politically. This is because the internet connects more people, entrepreneurs and even organizations. The development of technology in communication causes the increasing growth of internet users. This is also supported by the easy access to the internet anywhere and anytime because of the many possible accesses to support internet usage

Social media has experienced development in terms of function, where now social media is not only used as a means of interacting or sending words via messages, but now social media has been used more advanced to be able to do buying and selling business. One of them is the use of the social networks Facebook and Instagram, which are currently widely used for marketing, such as selling fashion, books, airplane tickets, food, and others.

With the number of online shops and social media being used for marketing, it will also increase competition between online businesses in attracting consumers. Consumers are the company's biggest asset. If a business wants to continue to grow and develop, the business actor must be able to understand and understand the various desires of its consumers. Consumers have unique and dynamic behavior in making purchase decisions.

The process of a consumer buying a product or service via the internet begins with the emergence of consumer awareness of an information or product obtained on the internet. Online shopping is a new form of communication that does not require face-to-face contact, but is carried out through notebooks, computers, or mobile phones that are connected to internet services. The online buying process has different steps to physical purchases. The uniqueness of the online buying process is when potential consumers use the internet and are looking for information related to the goods or services needed. 
As an entrepreneur, learning to understand consumer behavior in making purchase decisions is very useful. Competition is increasingly intense and consumer demands are diverse, understanding consumers is very important. Therefore, online businesses must have and carry out the right strategy in order to make internet users who have not made online purchases interested in making online purchases and can retain the customers they already have.

\section{METHODS OF RESEARCH}

The study builds consumer trust in digital marketing as an effort to strengthen the competitiveness of local umkm in this global era using a quantitative approach. Respondents of this study were consumers of UMKM products in the Greater Malang area who were taken as a representative sample with the conditions in the field. The probability sampling method is used to take samples with a total of 100 respondents. reference groups that are used as a reference for consumers in purchasing products through digital marketing. The results of data processing using descriptive analysis explain the field conditions of reference groups and consumer experiences in purchasing products through digital marketing

\section{RESULTS AND DISCUSSION}

Descriptions of Purchasing Experience and Reference Groups Used as Reference for Consumers in Purchasing Products through Digital Marketing as follows:

The frequency of purchasing products online. Currently, of course, almost everyone who owns a smartphone has an application that can be used to make purchases online. Online product purchases are made by consumers to meet the primary and secondary needs of these consumers. In this study, the frequency of consumers making online purchases is divided into 5 categories, namely very rarely, rarely, quite often, often and very often. The following are the results of research that shows the frequency of consumers making online purchases.

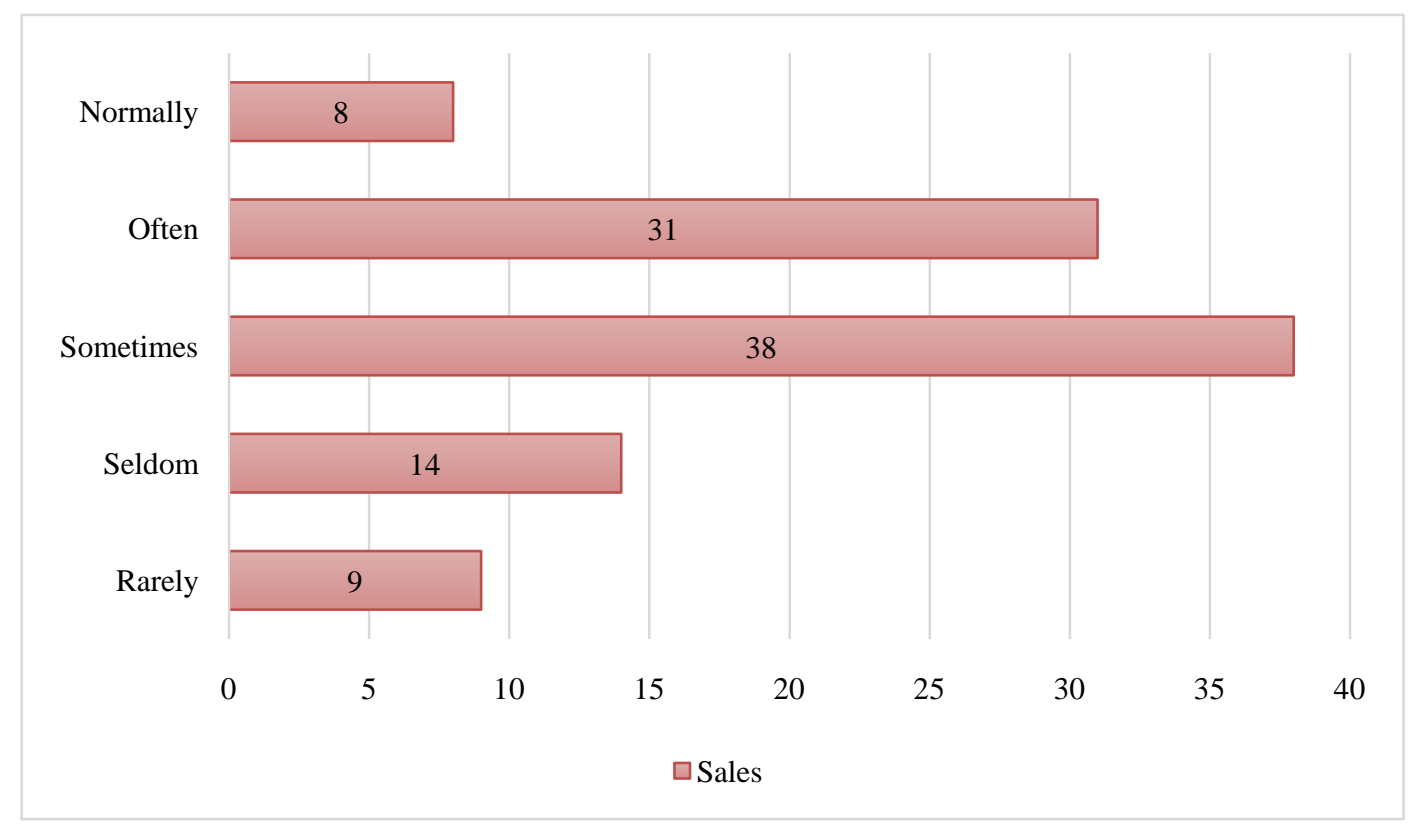

Figure 1 - Frecuency of Purchasing

Based on the survey results, respondents quite often buy products online; this is in accordance with the previous results which state that the level of purchasing of respondents during the pandemic has increased. Of the 100 respondents studied, there were 38 respondents who were quite frequent and 31 respondents who often made purchases online. 
From these data it can be seen that $69 \%$ of respondents buy products online. In order to prevent the spread of the Covid-19 virus pandemic, the government advises people not to be close together (social distancing), keep their distance (physical distancing), as well as implementing a work from home scheme so that employees always stay at home. This suggestion causes community activities to be limited so that people choose to shop online. This fairly frequent online purchase can be linked to panic buying made by the public. Based on the results of research conducted by Andras and Tamas (2020) that people make extra purchases to increase stocks at home in certain product groups. This panic buying will always be there.

The level of frequency of purchases during a pandemic. The current Corona outbreak has indeed resulted in changes in behavior in society, including changes in making purchases online. The following is data that shows the level of frequency of respondents making online purchases during a pandemic.

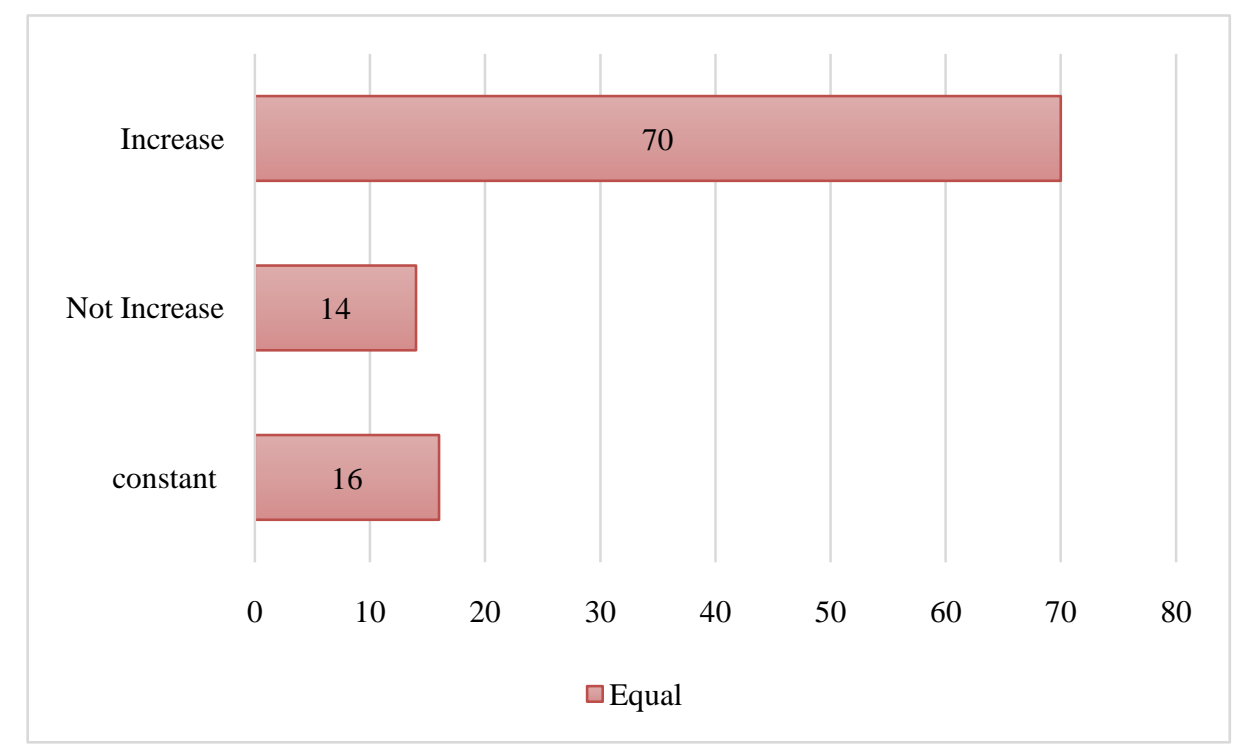

Figure 2 - The level of frequency of purchases during a pandemic



Figure 3 - Satisfaction level with the online purchasing experience 
The survey results show that during the pandemic, respondents often make purchases online. Of the 100 respondents studied, 70 respondents stated that they more often made purchases online. This is in accordance with Gusti (2020) who stated that during the Covid19 pandemic the number of online shop transactions had an increase of $400 \%$ and this is predicted to continue to increase. Increasingly increasing online purchases are quite mandatory because this is in accordance with government recommendations which advise all people not to carry out activities outside the home, so consumers prefer to make purchases online and stay at home. The following is the distribution of data regarding the frequency of respondents making purchases online during the pandemic.

Satisfaction level with the online purchasing experience. The level of satisfaction felt by consumers is an important thing that must be considered by producers, because the level of consumer satisfaction will determine consumer decisions in making repeat purchases in the same e-commerce. The following is data regarding the level of consumer satisfaction with the experience of making online purchases. Based on the results of the characteristics of the respondents, it can be concluded that consumers are satisfied with online purchases with results of 57 people.

Consumers feel satisfied or not with online purchases, one of which is the level of online shopping transactions and consumer trust. The formation of satisfaction will create consumer loyalty to the product, and create word of mouth marketing from consumers to others. This is supported by research conducted by Andhini (2017) which states that the ups and downs of consumer satisfaction with online purchases are determined by how high the level of online shopping transactions can be seen from the level of security, various preferences, and a good shopping experience obtained on online purchases. Besides that, it also maintains a good level of consumer confidence which can be seen from the fulfillment of every promise made by business actors, a reliable transaction process.

The distribution system of goods (accuracy of goods, speed of delivery, product safety, etc.) in marketing. Buying or selling products online, of course, requires a third party to connect producers with consumers. The product distribution system must be an important thing because it is an operational system.

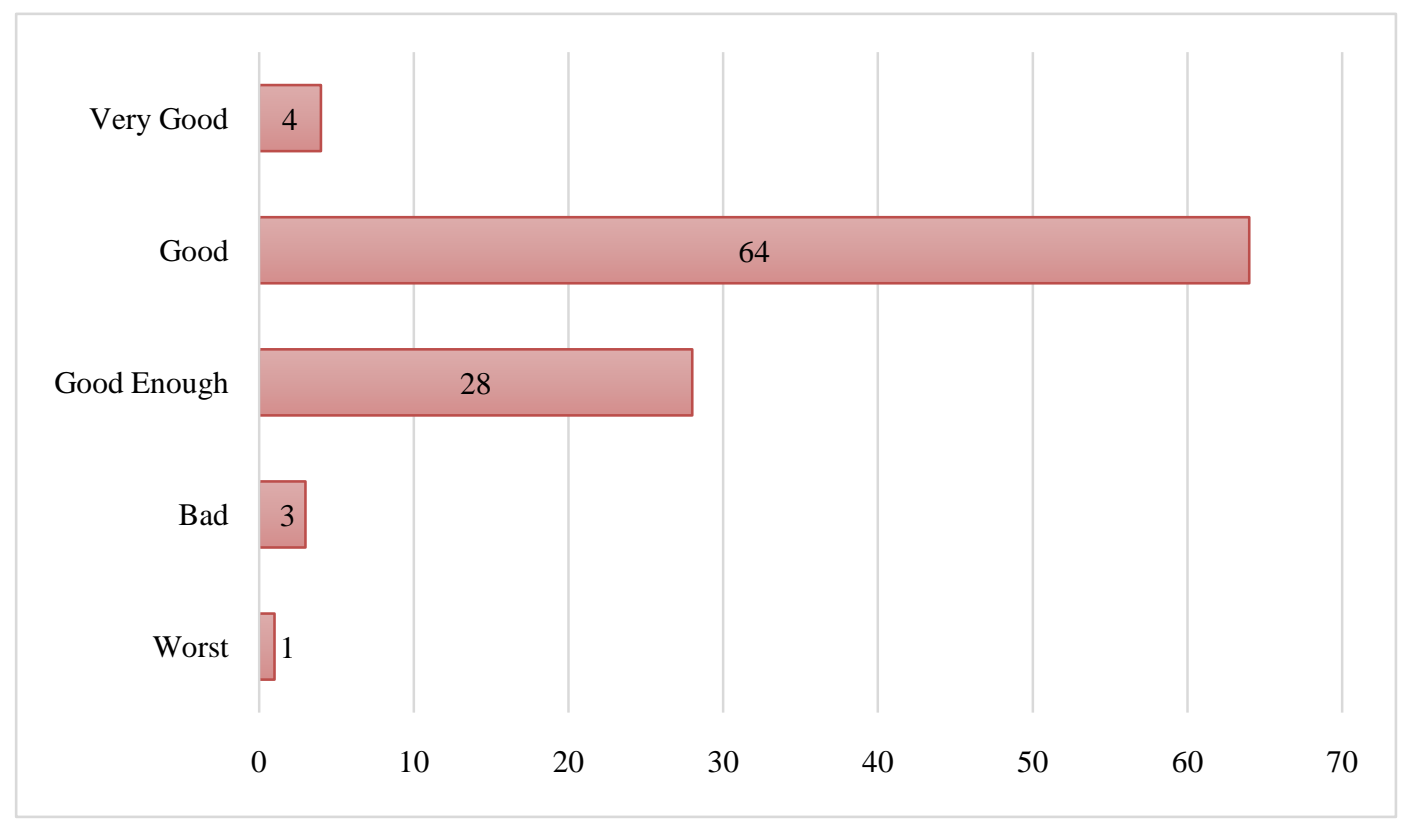

Figure 4 - Distribution System

Effective product distribution will provide added value by consumers for producers. The following is data that addresses consumer assessments of the distribution of goods when making purchases online. Based on the results of the characteristics of the respondents, it can be concluded that the distribution system of goods in online marketing 
has been said to be good with results of 64 people. The number of shipping services that consumers can choose according to their wishes is a major role in the continuity of good distribution of goods. This is supported by research conducted by Oktaviani et al (2018) which states that the reasons for consumers in choosing the highest shipping service are price, then delivery time, and packaging of goods, system services \& services, and then the number of branches. The best service from all the criteria that consumers want, namely J\&T in first, TIKI in second, JNE in third and WAHANA in fourth.

Payment system in online marketing. Purchasing online allows producers and consumers not to meet in person so that in order to continue sales transactions, consumers will first make payments online as well.

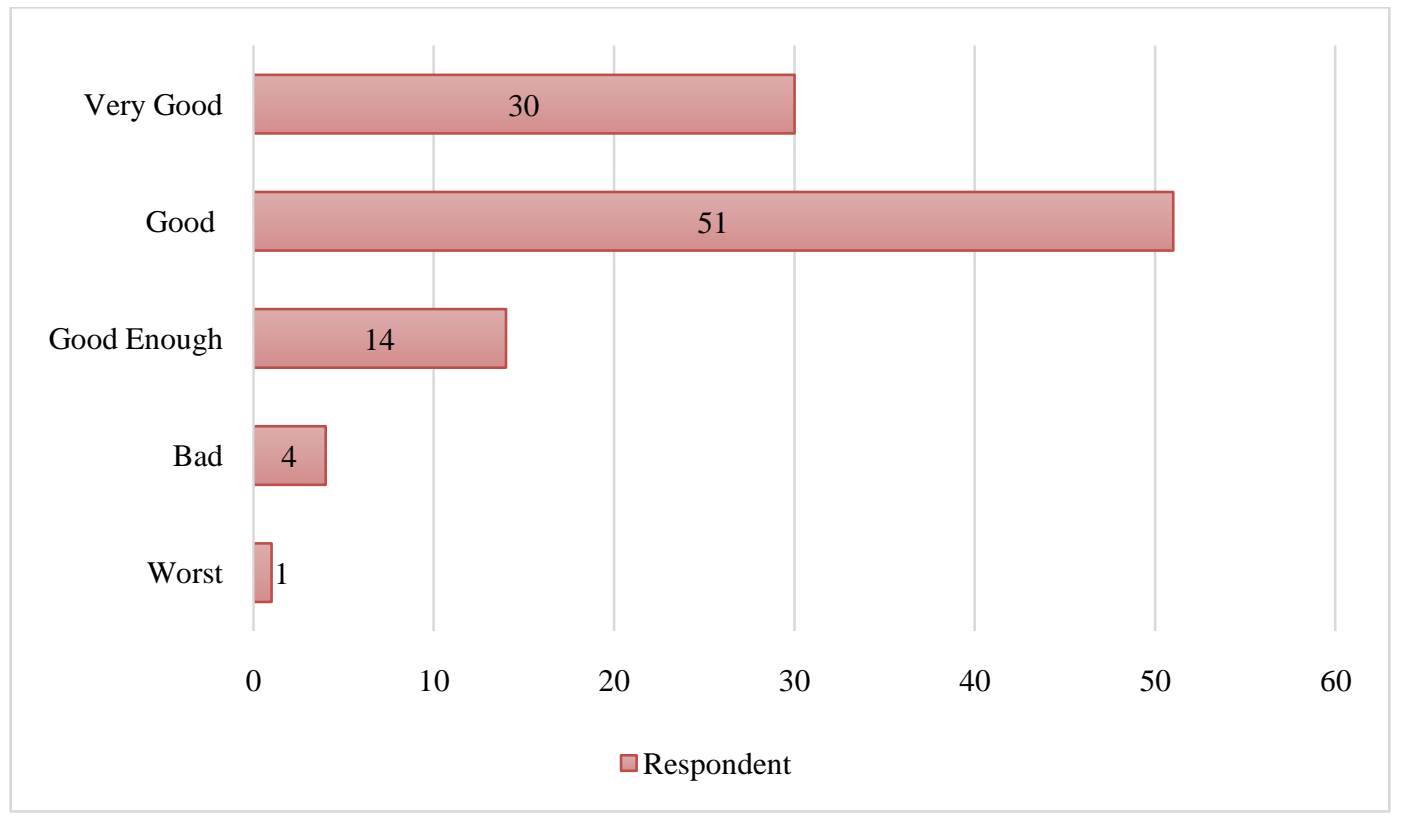

Figure 5 - Payment System

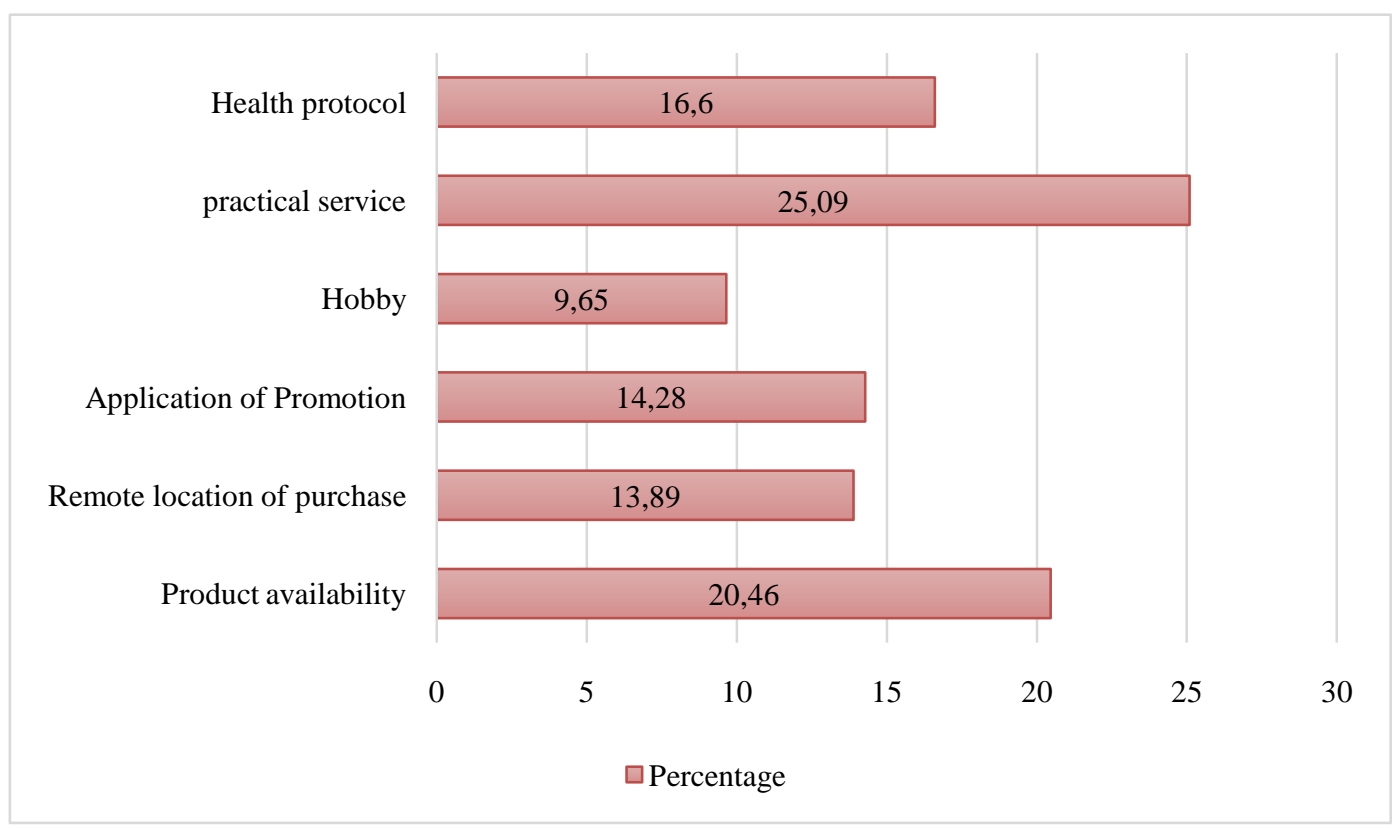

Figure 6 - Reasons for making purchases online

Based on the results of the characteristics of the respondents, it can be concluded that the online payment system is classified as easy and safe as evidenced by the results of 51 
people who said good and 30 people who said very good. The existence of online payments makes it easier to process transactions than conventional payments and also the many types of online payment systems make it more effective and efficient. This is supported by research conducted by Mulyasari et al (2014) which states that online payment systems can save time and effort and also online payment systems provide reliable security regarding payment transactions.

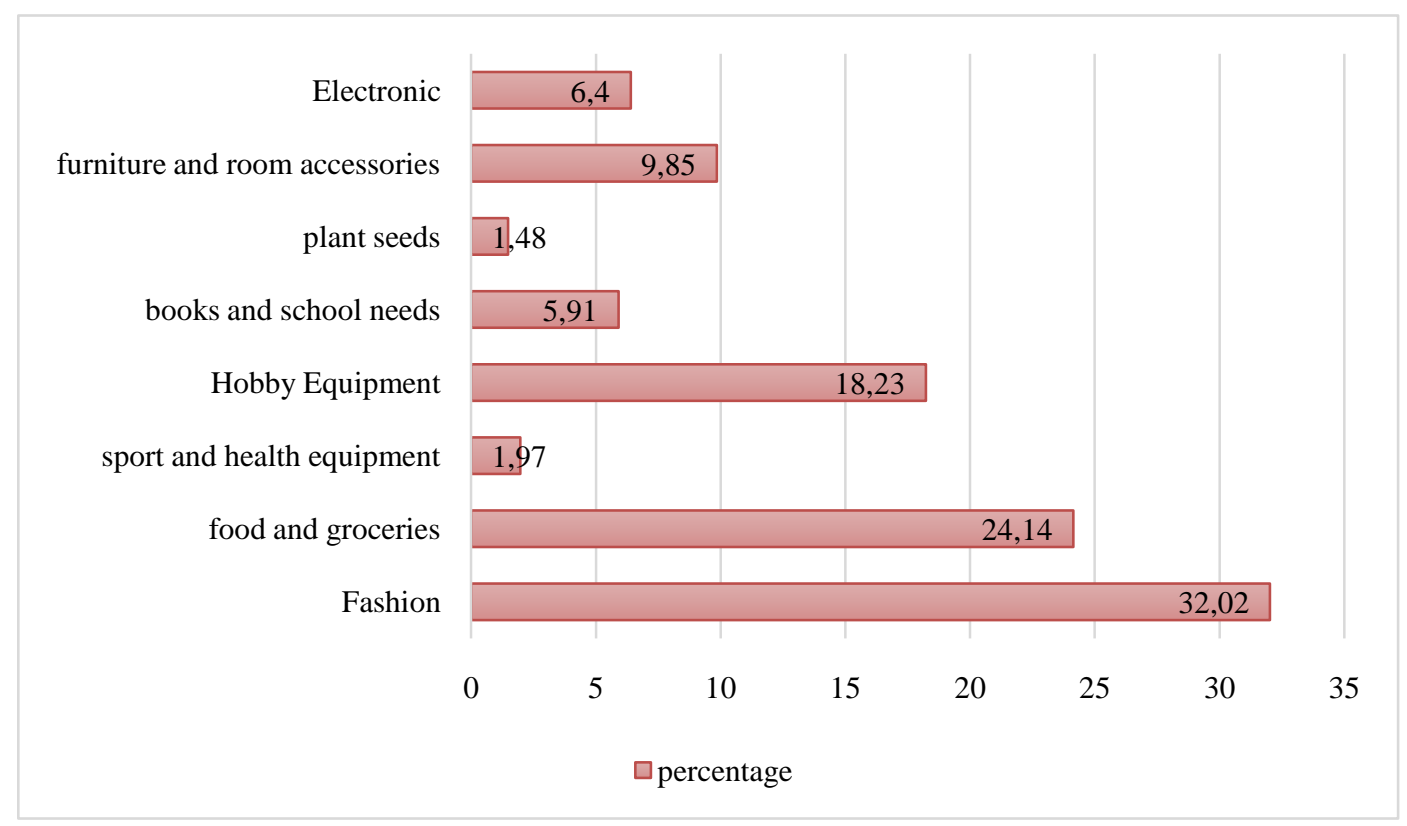

Figure 7 - What types of products are often purchased?

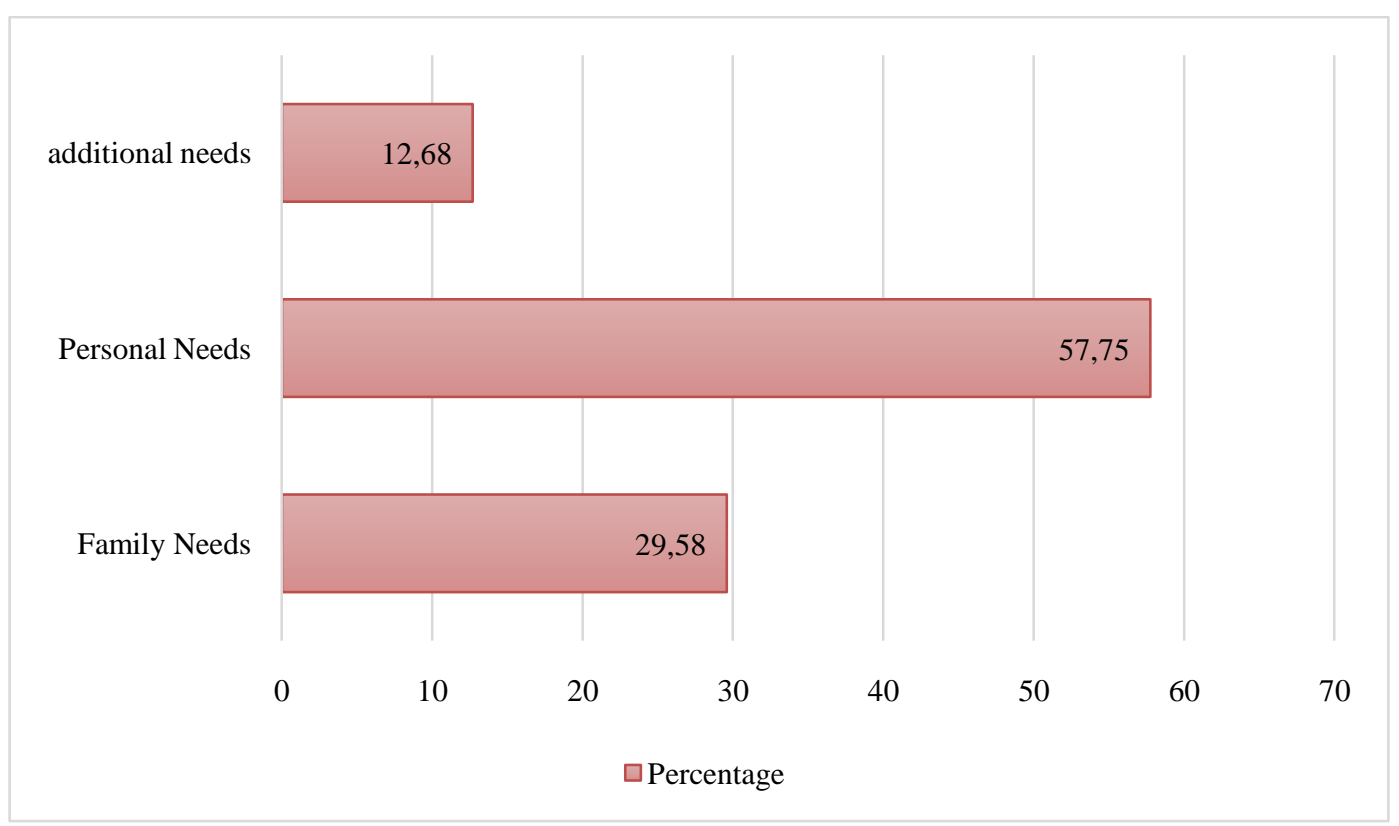

Figure 8 - The purpose of fulfilling needs through online purchases

Reasons for making purchases online. The development of the internet today is getting more and more widespread; even now people don't need to leave the house to make purchases to make ends meet. Practical services are the reasons that most encourage respondents to make purchases online, amounting to $25.10 \%$. The next reason that encourages respondents to make purchases online is the availability of various products, namely $20.46 \%$. This can be seen from the large number of product choices available in the 
product provider application, besides the product itself, usually substitute products for these products are also widely available so that consumers do not need to be confused if the available goods are not available.

What types of products are often purchased? The types of products purchased by consumers certainly influence consumer decisions in making purchases online. The products most frequently purchased by respondents when shopping online were fashion products, which amounted to $32.02 \%$, while the products that were least purchased were types of plant seeds and seeds, namely $1.97 \%$.

The purpose of fulfilling needs through online purchases. There are several fulfillment objectives to be achieved in making online purchases. Most consumers make purchases online for the purpose of fulfilling their personal needs. This is indicated by the percentage of the goal of fulfilling personal needs as much as $57.75 \%$, more than the goal of meeting family needs and additional needs.

\section{CONCLUSION AND SUGGESTIONS}

In general, the reference groups that influence digital product purchases are friends / spouses and family. So that the marketing approach and increasing consumer confidence must be built based on this closeness system through the purchase experience.

In order to enter digital marketing requires MSMEs to continue to increase their advantages in order to be able to win the competition. Some things that should be considered by MSMEs to increase the excellence of their products are product design and service guarantees. Product design needs to be done in order to attract consumers' attention to make purchases. In addition to product design, service guarantees are also important things that should be considered by MSMEs to increase excellence

\section{REFERENCES}

1. Adnan, Hooria. (2014). An Analysis of the Factors Affecting Online Purchasing Behavior of Pakistani Consumers. International Journal of Marketing Studies, 6 (5).

2. Arikunto, Suharsimi. (2010). Prosedur Penelitian Suatu Pendekatan Praktek. Jakarta: Rineka Cipta.

3. Ahmed, S. (2015). The Effects of Marketing Mix on Consumer Satisfaction: a Literature Review from Islamic Perspectives. Turkish Journal of Islamic Economics, 2(1), 17-17. https://doi.org/10.15238/tujise.2015.2. 1.17-30

4. Arham, M. (2010). Islamic perspectives on marketing. Journal of Islamic Marketing, 1(2), 149-164. https://doi.org/10.1108/175908310110 55888

5. Banica, L., Brinzea, V., \& Radulescu, M. (2015). Analyzing Social Networks from the Perspective of Marketing Decisions. Scientific Bulletin: Economic Sciences, 14(3), 37-50.

6. Cheng, J. H., \& Liu, S. F. (2017). A study of innovative product marketing strategies for technological SMEs. Journal of Interdisciplinary Mathematics, 20(1), 319- 337. https://doi.org/10.1080/09720502.2016.1258837.

7. Choudhury, P., Koo, W. W., \& Li, X. (2020). Working (From Home) During a Crisis: Online Social Contributions by Workers During the Coronavirus Shock Working (From Home) During a Crisis: Online Social Contributions by Workers During the Coronavirus Shock (Working Paper 20- 096).

8. Dolan, R., Conduit, J., Fahy, J., \& Goodman, S. (2017). Social media: communication strategies, engagement and future research directions. International Journal of Wine Business Research, 29(1), 2-19. https://doi.org/10.1108/lJWBR-04-2016-0013.

9. Forsythe, Sandra et al. (2006). Development of a Scale to Measure the Perceived and Risks of Online Shopping. Journal of Interactive Maketing, Vol. 20, No 2.

10. Gefen, D., Karahanna, E., \& Straub, D.W. (2003). Trust and TAM in Online Shopping: An Integrated Model. MIS Quaterly, 27 (1), 51-90.

11. Ghozali, I. (2011). Aplikasi Analisis Multivariate dengan Program IBM SPSS 19. Semarang: Badan Penerbit Universitas Diponegoro. 
12. Iswara, Danu. (2016). Pengaruh Kepercayaan, Kemudahan, Kualitas Informasi, dan Persepsi Risiko Terhadap Keputusan Pembelian (Studi Kasus pada Pengguna Media Sosial Instagram di Kota Yogyakarta). Skripsi. Universitas Negeri Yogyakarta.

13. Kim, Jae et al. (2004). Factors Affecting Online Search Intentinon abd Online Purchase Intention. Seoul Journal of Businnes.

14. Kotler, Philip \& Gary Amstrong. (2008). Prinsip-Prnsip Pemasaran. Jakarta: Erlangga.

15. Kuncoro, Mudrajad. (2003). Metode Riset untuk Bisnis dan Ekonomi. Jakarta: Erlangga.Laudon, Kenneth \& Jane P. Laudon. (2004). Sistem Informasi Manajemen: Mengelola Perusahaan Digital. Yogyakarta: ANDI.

16. Mulyasari, H., Dan, T. T. B., \& Wijaya, A. B. M. 2011. Analisis Jenis Sistem Pembayaran Elektronik dalam Transaksi E-Commerce Di Indonesia. The Electronic Journal on Information Systems in Developing Countries, 49, 1-16.

17. Purkayastha, A., \& Sharma, S. (2016). Gaining competitive advantage through the right business model: analysis based on case studies. Journal of Strategy and Management, 9(2), 138-155.

18. Rangaswami, A., \& Gupta, S. (2000). Innovation Adoption and Diffusion in the Digital Environments: Some Research Opportunities. In In Vijay Mahajan, Eitan Muller, and Yoram Wind (Eds.), New Product Diffusion Models (pp. 85-101). Springer. https://doi.org/10.1080/135272609027 57506 Royle, J., \& Laing, A. (2014). The digital marketing skills gap: Developing a Digital Marketer Model for the communication industries. International Journal of Information Management, 34(2), 65-73. https://doi.org/10.1016/j.jijinfomgt.201 3.11.008

19. Sarker, A. A. (2001). Islamic Business Contracts, Agency Problem and the Theory of the Islamic Firm. International Journal of Islamic Financial Services, 1(2), 01-15. https://doi.org/10.1093/jis/12.3.329

20. Srinivisan R, Bajaj R, Bhanot S. 2016. Impact of social media marketing strategies used by micro, small, and medium enterprises (MSMEs) on customer acquisition and retention. Journal Business and Management 18(1): 91-101. Stockdale R, Ahmed A, Scheepers H. 2012. Identifying business value from the use of social media: an sme perspective. PACIS Proceeding. Association for Information System Electronic Library.

21. Vishal Midha, Article- Impact of Consumer Empowerment on Online Trust: An Examination Across Genders, Elsevier International Journal, 12(3), 2012, 198-205

22. Waghmare GT, E-Commerce, A Business Review and Future Prospects in Indian Business. Internet, Marketing in India. Indian Streams Research Journal, 2(5), 2012, 1- 4. 